University of Nebraska - Lincoln

DigitalCommons@University of Nebraska - Lincoln

Mammalogy Papers: University of Nebraska

State Museum

Museum, University of Nebraska State

2012

\title{
Examination of Annual Variation in the Adult Sex Ratio of \\ Pronghorn (Antilocapra americana)
}

Justin D. Hoffman

McNeese State University, jhoffman@mcneese.edu

Hugh H. Genoways

University of Nebraska State Museum, h.h.genoways@gmail.com

Follow this and additional works at: https://digitalcommons.unl.edu/museummammalogy

Part of the Zoology Commons

Hoffman, Justin D. and Genoways, Hugh H., "Examination of Annual Variation in the Adult Sex Ratio of Pronghorn (Antilocapra americana)" (2012). Mammalogy Papers: University of Nebraska State Museum. 161.

https://digitalcommons.unl.edu/museummammalogy/161

This Article is brought to you for free and open access by the Museum, University of Nebraska State at DigitalCommons@University of Nebraska - Lincoln. It has been accepted for inclusion in Mammalogy Papers: University of Nebraska State Museum by an authorized administrator of DigitalCommons@University of Nebraska Lincoln. 


\title{
Examination of Annual Variation in the Adult Sex Ratio of Pronghorn (Antilocapra americana)
}

\author{
JUSTIN D. HOFFMAN ${ }^{1}$ \\ Department of Biological and Health Sciences, McNeese State University, Lake Charles, Louisiana 70609
}

AND

HUGH H. GENOWAYS

University of Nebraska State Museum, University of Nebraska, Lincoln 68588

\begin{abstract}
The adult sex ratio (ASR) is an important component of a population's demographics and can be used as an indicator of a population's status. However, the causes of annual variation in ASRs are unknown for many species. Fluctuations in ASR can arise through demographic stochasticity and intense selective harvesting. In this study we investigate the longterm patterns of variation in the ASRs (bucks: 100 does) for four populations of pronghorn (Antilocapra americana) in western Nebraska. We used multiple variables in a model selection process to predict annual fluctuation of pronghorn ASRs. We found that the number of bucks: 100 does significantly varied over the four populations. The best predictors of annual variation in pronghorn ASRs were variable across all populations. The number of pronghorn bucks harvested in the previous year's hunting season and the previous year's density of pronghorn were the most common predictors of ASR fluctuation. Buck harvest was an important predictor variable in only two of the four populations. Variation of harvest strategies within the populations could account for the lack of importance of buck harvest in half of the populations. The relationship between density and ASR is novel but difficult to interpret due to lack of data on birth sex ratios and fawn survival. More data on pronghorn demographics are needed in order to better explain the connection between density and ASR.
\end{abstract}

\section{INTRODUCTION}

The adult sex ratio (ASR) is an important component of a population's demographics. Skewed ASRs have been linked to breeding behavior, social status, and the reproductive success of individuals (Murray, 1991; Clutton-Brock et al., 1997; Castro et al., 2004). ASRs are important indicators of a population's status and are a commonly used index for population management (White et al., 2001; Clutton-Brock et al., 2002; McLoughlin et al., 2005; Solberg et al., 2005). However for most species, little is known of the specific causes of annual variation in ASRs and the impacts they have on population dynamics (Le Galliard et al., 2005). Fluctuations in ASRs can be the result of demographic stochasticity, which arises from variation in birth sex ratios and survival rates of offspring until adulthood (Lee et al., 2011). Also, intense selective harvesting of populations can cause annual variations in ASR (Ginsberg and Milner-Gulland, 1994; Bender and Miller, 1999; Milner-Gulland et al., 2003; Milner et al., 2007). Understanding what factors cause annual variation in the ASR of a population will assist biologists in conserving populations that possess high levels of demographic stochasticity or manage important game species that are subject to an intense annual harvest (Wildt and Wemmer, 1999; Wedekind, 2002; Bessa-Gomes et al., 2004).

Different mating systems often result in different patterns of ASRs. Birds, which typically possess monogamous mating systems, tend to have an equal or slightly male-biased ASR,

\footnotetext{
${ }^{1}$ Corresponding author: Telephone: (337) 475-5659; FAX: (337) 475-5677; e-mail: jhoffman@ mcneese.edu
} 
whereas species with polygynous mating systems, such as mammals, possess ASRs that are typically female-biased (Berger and Gompper, 1999; Donald, 2007). Reproductive capacity in polygynous animals is highest when a few dominant males control the mating rights to several females (Bessa-Gomes et al., 2004); however, these populations are highly vulnerable to forms of demographic stochasticity, such as variation in sex ratios (Stephens et al., 1999; Engen et al., 2003; Sæther et al., 2004). As a result, annual oscillations in ASR could have important management implications by reducing the reproductive potential of a population. This can be especially problematic if an Allee effect (Allee, 1931) is present in the population. An Allee effect refers to a situation where the per capita rate of population growth becomes negative as population density or size decreases (Stephens et al., 1999). Allee effects have multiple conservation concerns because demographic stochasticity could result in increased probabilities of extinction in small populations (Courchamp et al., 1999). Engen et al. (2003) demonstrated that fluctuations in the sex ratio will add additional components of demographic variance to a population; therefore, extreme shifts in a populations ASR could lead to a loss of reproductive potential and decrease the population growth rates (Le Galliard et al., 2005).

Pronghorn (Antilocapra americana) are an important game animal in several states and provinces (O'Gara and Yoakum, 2004); however, little is known about the variation and drivers of ASR among their populations. A recent study of four populations of pronghorn in Nebraska reported significant annual variation in density and recruitment (Hoffman et al., 2010). Each population also was shown to possess characteristics of an Allee effect, where the per capita population growth became negative once density crossed a certain threshold. Given the lack of information regarding causes of ASR fluctuations a detailed analysis of ASR variation within the populations of Nebraska pronghorn is warranted. The objectives of our research were to (1) compare long-term variations in the ASR among four populations of pronghorn in Nebraska, and (2) identify the variables that best predict annual fluctuations of the ASR within the four populations.

\section{Materials ANd Methods}

Populations of pronghorn were monitored through aerial line transect surveys in western Nebraska beginning in 1955. Locations of surveys corresponded to four established pronghorn management units (PMUs): Sioux, Box Butte, Garden, and Banner. Site descriptions and locations of each PMU can be found in Hoffman et al. (2010). We believe that these survey units represent independent pronghorn populations because all of the survey units are separated by a matrix of paved highways and fences, which severely restrict pronghorn movements (Deblinger et al., 1984; Ockenfels et al., 1992; Yoakum, 2004).

Using a fixed-wing aircraft, transects were surveyed during Jul. of each year within each PMU. Transects were located between 2.4 and $4.8 \mathrm{~km}$ apart and surveyed at $30 \mathrm{~m}$ above ground level. The number of male and female pronghorn observed within $0.4 \mathrm{~km}$ on either side of the midline of the transect were counted by two observers. From these data the adult buck: doe ratio was determined. We used data on pronghorn ASR collected during 19551993 for Sioux, Box Butte, and Garden PMUs, and 1964-1993 for the Banner PMU. Aerial surveys continued beyond 1993; however, we chose to exclude post-1993 data from the analysis because some of the survey locations had changed and there was an absence of surveys during certain years for some units. Unfortunately, no corrections for sightability or estimates of error for buck: doe ratios were calculated. We assumed that the relative consistency in the survey methodology over the years minimized the effects these had on our results. 
TABLE 1.-Model structure of 13 a priori models based on number of does harvested (Doe_har), number of bucks harvested (Buck_har), spring precipitation (Spring_p), snow depth (Snow_d), and density of pronghorn in the previous year (Density). The models were used to predict annual variation in the adult sex ratios of pronghorn (Antilocapra americana) in four populations in Nebraska

\begin{tabular}{cl}
\hline \hline Model No. & \multicolumn{1}{c}{ Model variables } \\
\hline 1 & Doe_har \\
2 & Buck_har \\
3 & Spring_p \\
4 & Snow_d \\
5 & Density \\
6 & Null \\
7 & Density + Doe_har \\
8 & Snow_d + Buck_har \\
9 & Density + Buck_har \\
10 & Density + Snow_d + Doe_har \\
11 & Density + Spring_P + Buck_har \\
12 & Density + Spring_P + Snow_d + Doe_har \\
13 & Density + Spring_P + Snow_d + Buck_har \\
\hline
\end{tabular}

To determine potential causes in the fluctuation of pronghorn buck: doe ratios, we collected data on several independent variables that we felt could influence the ASR of pronghorn in the study area. We collected data on spring precipitation (Spring_p) and snow depth (Snow_d) from the High Plains Regional Climate Center (http://www.hprcc. unl.edu/), which can indirectly affect the health and survival of individuals. Spring precipitation can affect the quality and quantity of forage in grassland habitats, and snow depth can restrict access to adequate forage during the winter. Locations of the climate stations were variable with respect to locations of the survey areas, but we collected data from the station that was closest to the center of each survey area. Spring precipitation was calculated as the average rainfall from Apr. to Jun. of each survey year, and snow depth was averaged from Oct. of the previous year to Apr. of the survey year. Pronghorn density (Density) from the previous year as reported by Hoffman et al. (2010) was used as a potential predictor variable. Varying densities can result in an adjustment of a population's sex ratio (Trivers and Willard, 1973). Finally, we collected data on the number of bucks (Buck_har) and does (Doe_har) removed from the population during the previous year's harvest. Data on pronghorn harvest were available for the entire PMU, not just the survey area. Because of these discrepancies, a correction was performed on the harvest data so that only a proportion of the survey areas that fell within each county were represented. This correction consisted of multiplying the total number of bucks and does harvested in a PMU by the proportion of unit that was surveyed.

We performed a one-way analysis of variance (ANOVA) with a Tukey HSD post-hoc test to determine if ASRs significantly differed among PMUs. To investigate fluctuations in pronghorn ASRs we used a model selection approach (Burnham and Anderson, 2002). We constructed 13 candidate models a priori with ASR as the response variable. A correlation matrix was performed on all explanatory variables to test for multicollinearity before constructing the candidate models. We considered any variables with $\mathrm{r}^{2}>0.5$ as correlated (Leathwick et al., 2005). The harvest of bucks (Buck_har) and does (Doe_har) were highly correlated in all populations, thus were not included in the same model. All other combinations of explanatory variables for each population were not correlated. The suite 

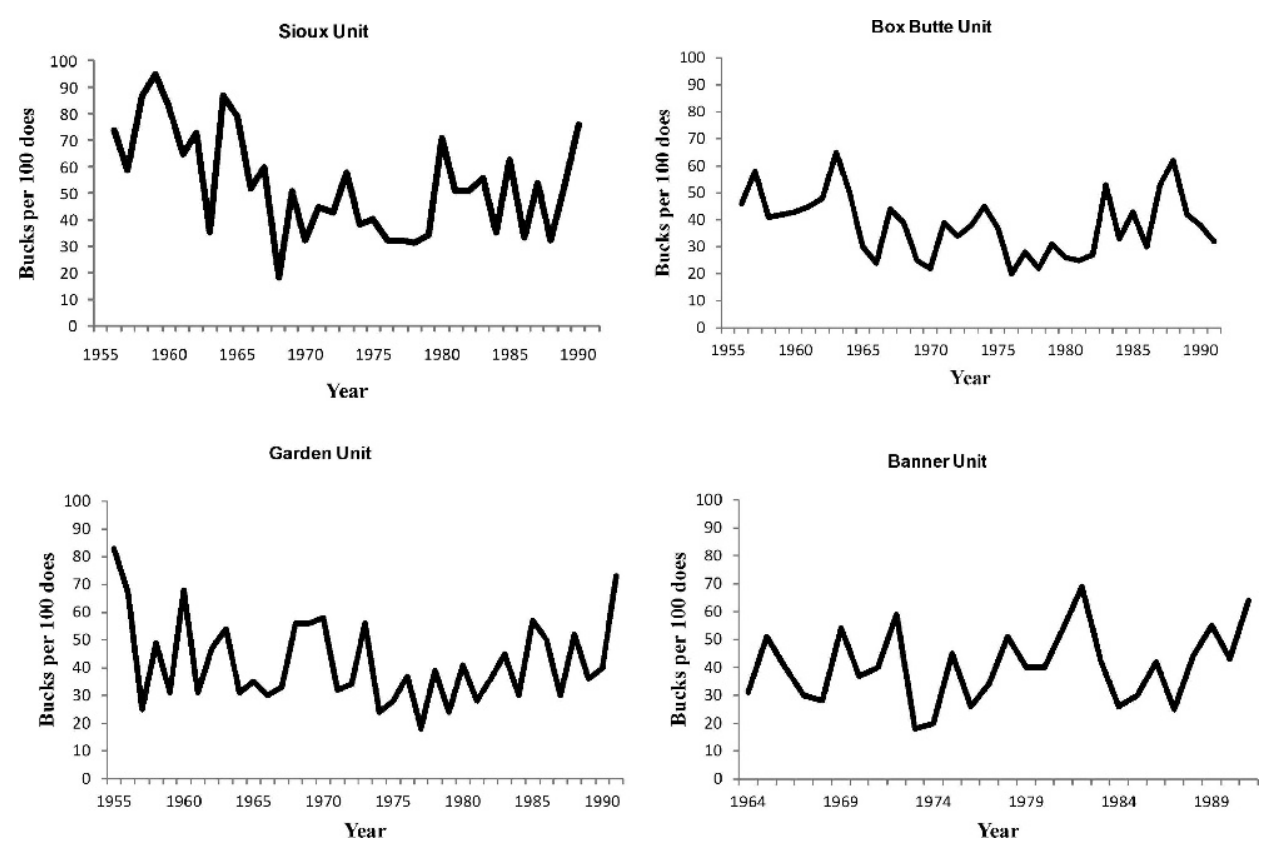

Fig. 1.-Trends of pronghorn (Antilocapra americana) adult sex ratios (ASR) for 4 management units in western Nebraska based on aerial surveys conducted annually during Jul. from 1955 to 1993

of candidate models included all single variable models, a global model that possessed all noncorrelated variables, and various combinations of predictor variables (Table 1). We also included a null model ["response $=(1)$ "'] which predicts that pronghorn ASRs are random with respect to all variables. The same candidate models were used to predict fluctuations of ASR in all four populations of pronghorn.

We used a generalized linear model (GLM) with a quasi-Poisson link function to fit the models to the data (Burnham and Anderson, 2002). Since our response variable consisted of count data, a Poisson distribution was used. The quasi-Poisson link was used to account for overdispersion in the count data. We calculated quasi-AIC (QAIC) values for the models predicting ASRs to determine the best fit model. The model with the lowest QAIC value was considered the best-approximating model, and models with $\triangle$ QAIC $<2$ were considered significant and equally supported (Burnham and Anderson, 2002). For each model with a $\triangle$ QAIC $<2$, we calculated Akaike model weights $(w)$ to represent the probability of best fit among all candidate models (Burnham and Anderson, 2002). If more than one candidate model was equally supported, we performed a model averaging procedure among all the significant models $(\triangle \mathrm{QAIC}<2)$. This provided us with the average coefficient estimate, sE, $95 \%$ confidence intervals, and relative importance of the parameters. This approach allowed us to use all significant models for inference. Finally, to examine the relationship between individual variables and pronghorn ASR we performed linear regressions between ASR and all significant explanatory variables in each PMU. All statistical analyses were performed using $\mathrm{R}$ (2.9.2) statistical software (R Development Core Team, 2008). 
TABLE 2.-Quasi-Akaike Information Criteria (QAIC) scores, differences in QAIC score between the $i$ th and top-ranked model ( $\triangle$ QAIC), Quasi-Akaike weights $(\mathrm{w})$, and number of variables $(\mathrm{k})$ for models predicting ASRs of pronghorn (Antilocapra americana) in Nebraska for four pronghorn management units. Only models with $\Delta$ QAIC $<2.0$ are reported

\begin{tabular}{lcccc}
\hline \hline \multicolumn{1}{c}{ Model variables } & QAIC & $\Delta$ QAIC & $w$ & $\mathrm{k}$ \\
\hline Sioux Unit & & & & \\
Buck_har & 176.20 & 0.00 & 0.313 & 3 \\
Density + Buck_har & 176.52 & 0.32 & 0.266 & 4 \\
Density + Spring_P + Buck_har & 176.57 & 0.37 & 0.260 & 5 \\
Box Butte Unit & & & & \\
Density + Doe_har & 152.46 & 0.00 & 0.272 & 4 \\
Density & 152.55 & 0.09 & 0.260 & 3 \\
Density + Snow_d + Doe_har & 153.33 & 0.87 & 0.176 & 5 \\
Garden Unit & & & & \\
Density + Buck_har & 166.07 & 0.00 & 0.267 & 4 \\
Buck_har & 166.22 & 0.15 & 0.248 & 3 \\
Density & 166.87 & 0.80 & 0.179 & 3 \\
Banner Unit & & & & \\
Null & 132.81 & 0.00 & 0.216 & 2 \\
Snow_d & 132.87 & 0.07 & 0.209 & 3 \\
Density & 134.02 & 1.22 & 0.117 & 3 \\
Snow_d + Buck_har & 134.35 & 1.55 & 0.100 & 4 \\
Buck_har & 134.48 & 1.67 & 0.094 & 3 \\
\hline
\end{tabular}

\section{RESULTS}

We observed annual variation in the ASR within each pronghorn population as well as variation in ASRs among the different populations surveyed (Fig. 1). The Sioux PMU population consisted of approximately 35\% bucks, where the average number of bucks: 100 does is 53 (range $=18-95$ bucks: 100 does). The Sioux population was the least femalebiased among all PMUs, although the range between minimum and maximum bucks: 100 does was the widest. The Box Butte PMU possessed the most female-biased population of pronghorn on average. Approximately $28 \%$ of the Box Butte population consisted of bucks with an average of 38 bucks: 100 does (range $=20-65$ bucks: 100 does). In the Garden PMU, 29\% of the population consisted of bucks with an average of 42 bucks: 100 does (range $=18-83$ bucks: 100 does). Finally, the pronghorn population in the Banner PMU consisted of $30 \%$ bucks and averaged 40 bucks: 100 does (range $=13-69$ bucks: 100 does). The number of bucks: 100 does differed significantly across the four PMUs $\left(\mathrm{F}_{(3,140)}=5.19\right.$, $\mathrm{P}=0.001)$. Tukey post-hoc comparisons indicated the ASR was significantly higher in the Sioux PMU compared to the Box Butte [95\% CI $(0.037,0.232), \mathrm{P}=0.002$ ], Garden [95\% CI (0.003 0.196), $\mathrm{P}=0.04$ ], and Banner [95\% CI $(0.021,0.215), \mathrm{P}=0.01$ ] units. All other pairwise comparisons between PMUs indicated no significant difference in number of bucks.

Our results indicate that population density and the previous year's buck harvest were the best indicators of annual fluctuations in pronghorn ASRs. In the Sioux PMU three models best fit the data with $\triangle$ QAIC $<2$ (Table 2 ). These three models comprised $83 \%$ of all model weights. Model averaging of all significant models in the Sioux PMU showed that the previous year's buck harvest (Buck_har) was the only significant variable (Table 3). The 
TABLE 3.-Model average estimates of intercept and coefficients for the best fit models $(\Delta$ QAIC $<2)$ that predicts pronghorn (Antilocapra americana) ASRs in Nebraska for four pronghorn management units (significant variables are highlighted). Standard errors, parameter weights across all best fit models, and $95 \%$ lower and upper confidence limits are also listed

\begin{tabular}{|c|c|c|c|c|c|}
\hline & Estimate & $\mathrm{SE}$ & $w$ & UCL & LCL \\
\hline \multicolumn{6}{|l|}{ Sioux Unit } \\
\hline (Intercept) & 4.380 & 0.150 & - & 4.680 & 4.090 \\
\hline Buck_har & -0.003 & 0.004 & 0.84 & -0.002 & -0.004 \\
\hline Density & 0.020 & 0.010 & 0.53 & 0.040 & -0.010 \\
\hline Spring_p & 0.060 & 0.040 & 0.26 & 0.140 & -0.010 \\
\hline \multicolumn{6}{|c|}{ Box Butte Unit } \\
\hline (Intercept) & 3.830 & 0.100 & - & 4.020 & 3.640 \\
\hline Density & -0.100 & 0.040 & 0.71 & -0.020 & -0.170 \\
\hline Snow_d & -0.030 & 0.020 & 0.18 & 0.010 & -0.070 \\
\hline Doe_har & 0.001 & 0.001 & 0.45 & 0.002 & -0.001 \\
\hline \multicolumn{6}{|l|}{ Garden Unit } \\
\hline (Intercept) & 3.920 & 0.080 & - & 4.060 & 3.770 \\
\hline Density & -0.710 & 0.360 & 0.45 & -0.010 & -1.410 \\
\hline Buck_har & -0.002 & 0.001 & 0.52 & -0.001 & -0.004 \\
\hline \multicolumn{6}{|l|}{ Banner Unit } \\
\hline (Intercept) & 0.600 & 0.910 & - & -1.210 & 2.380 \\
\hline "1", 1 & - & - & 0.22 & - & - \\
\hline Density & 0.090 & 0.080 & 0.12 & 0.240 & -0.060 \\
\hline Snow_d & 0.040 & 0.020 & 0.31 & 0.080 & -0.010 \\
\hline Buck_har & -0.001 & 0.001 & 0.19 & 0.001 & -0.002 \\
\hline
\end{tabular}

parameter estimate indicated a negative relationship between buck harvest and ASR. In the Box Butte PMU, three models enjoyed equal support for explaining fluctuations in ASRs of pronghorn (Table 2). These three models comprised approximately $71 \%$ of all model weights. Results of the model averaging indicated that population density of pronghorn (Density) was the only significant variable for explaining annual variation in the ASR of pronghorn in the Box Butte PMU and was negatively correlated to the ASR (Table 3). In the Garden PMU, three models were found to be significant $(\triangle$ QAIC $<2)$ in predicting pronghorn ASRs (Table 2) and included $69 \%$ of the model weights. Model averaging indicated that both population density (Density) and the previous year's buck harvest (Buck_har) were significant variables (Table 3). Both of these variables possess negative parameter estimates indicating an inverse relationship with ASRs. In the Banner PMU, five models were equally supported in explaining annual variations in ASRs (Table 2); however, among the significant models for the Banner PMU was the Null model. This indicates that the variables used did not predict variation in the ASR any better than chance. Further, none of the other variables found in the best fit models was significant (Table 3 ).

In two PMUs (Box Butte and Garden), pronghorn density of the previous year showed a significant non-linear trend with pronghorn ASR (Fig. 2). In both instances, as population density decreased, the adult sex ratios become less female-biased. The ASR begins increasing sharply as density falls below 2.0 (inds. $/ \mathrm{km}^{2}$ ) in the Box Butte PMU and 0.4 (inds. $/ \mathrm{km}^{2}$ ) in the Garden PMU. Also in the Sioux and Garden PMUs, the number of males harvested in the previous year's hunting season was significantly correlated with adult sex 

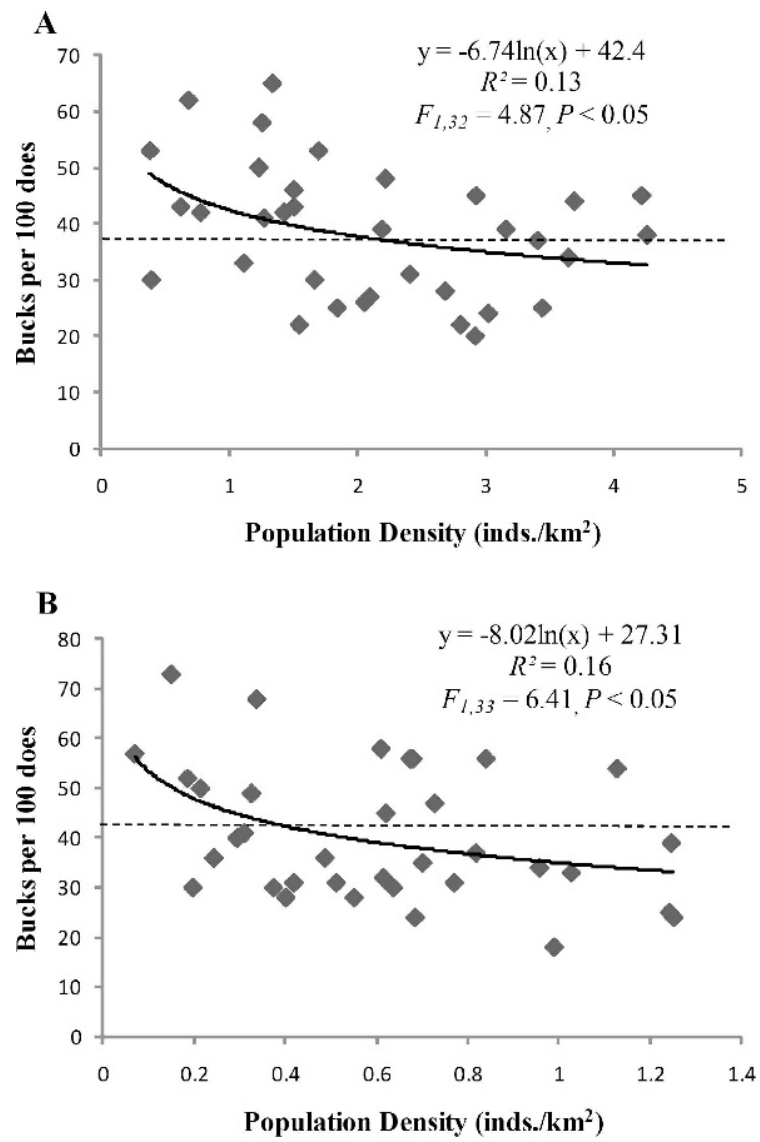

Fig. 2.-Logarithmic number of pronghorn (Antilocapra americana) bucks per 100 does and pronghorn density in the previous year for the Box Butte (A) and Garden (B) pronghorn management units in western Nebraska during 1955-1993. Linear equations and lines are provided for the regression model that best fit the data. The dashed line represents the mean number of bucks per 100 does over the course of the study period

ratios (Fig. 3). As more males were removed from the Sioux and Garden PMUs, the pronghorn ASR became more female-biased the following year.

\section{Discussion}

The pronghorn ASR was not significantly different among the Box Butte, Banner, and Garden units, whereas the ASR was significantly higher in the Sioux PMU. The pronghorn ASR in the Sioux PMU averaged 53 bucks: 100 does over the course of the study. This number is comparable to other studies of pronghorn ASR. For instance, Pojar et al. (1995) documented an average pronghorn ASR of 54 bucks: 100 does in Colorado over the span of 4 y using multiple survey techniques in shortgrass prairie habitat. Woolley and Lindzey (1997) used two observers to survey three sites in Wyoming and reported average number of bucks: 100 does of 48, 58, and 24, respectively. In a pronghorn population in Nevada, Maher 

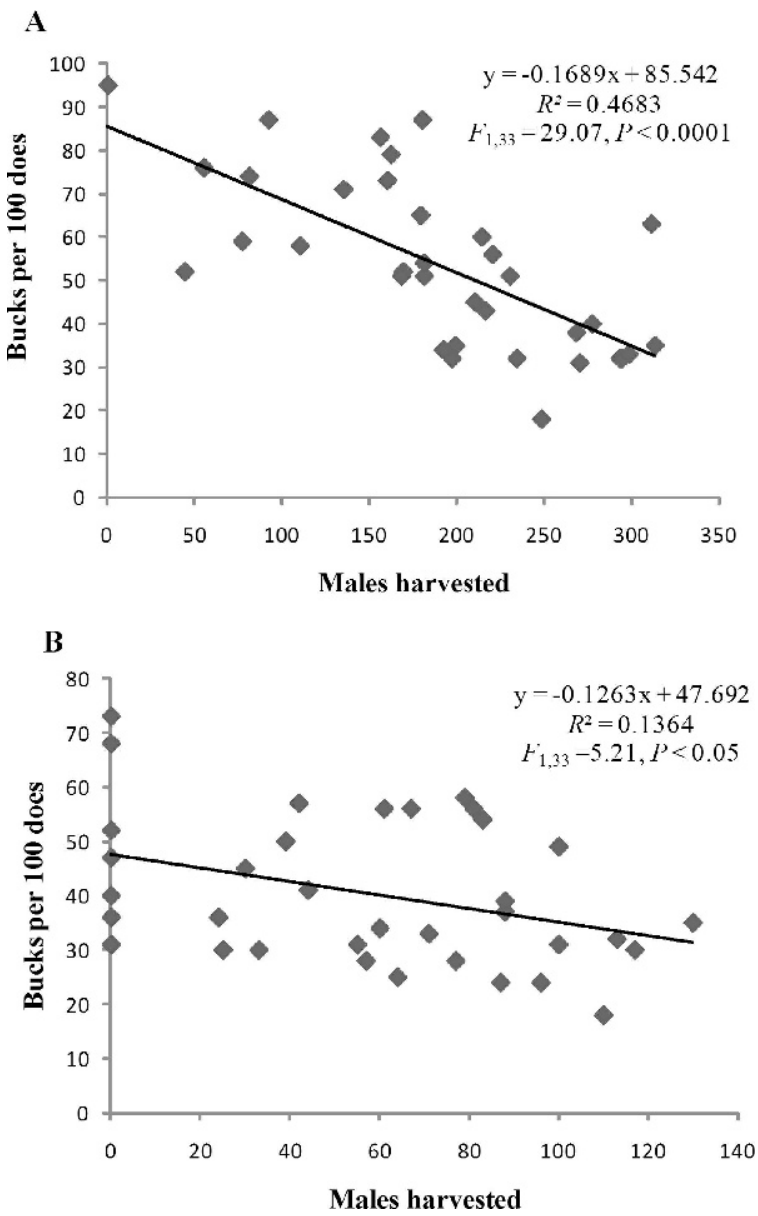

FIG. 3.-Regression of the number of pronghorn (Antilocapra americana) bucks per 100 does and the number of bucks harvest in the previous year's hunting season for the Sioux (A) and Garden (B) pronghorn management units in western Nebraska from 1955-1993. Linear equations and lines are provided for the regression model that best fit the data. Zero values in the buck harvest data, which correspond to years where pronghorn hunting was suspended, prevented a log-transformation of the data

(1991) found an ASR of 50 bucks: 100 does. The relatively lower number of bucks in the Box Butte, Banner, and Garden units compared to the Sioux PMU could be due to the overall quality of habitat found in these units. Quality habitat for pronghorn include areas with sufficient forage, fawn bedding cover, and low growing vegetation to facilitate predator detection; all of which are most often found in shortgrass prairies (Yoakum, 2004). The Sioux PMU is comprised mostly of Western shortgrass prairie habitat (Table 4) and supports a considerably higher density of pronghorns $\left(9.1\right.$ inds. $\left./ \mathrm{km}^{2}\right)$ than the Box Butte $\left(1.9\right.$ inds. $\left./ \mathrm{km}^{2}\right)$, Banner $\left(1.3\right.$ inds. $\left./ \mathrm{km}^{2}\right)$, and Garden $\left(0.6\right.$ inds. $\left./ \mathrm{km}^{2}\right)$ units, which consist of a mosaic of shortgrass and mid-grass prairies and agricultural land (Table 4). The midgrass prairie and agricultural habitats may not provide adequate year round forage for 
TABLE 4.-Landcover characteristics for four pronghorn management units (PMU) in western Nebraska. These data were extracted from the Nebraska Gap Analysis Program (GAP) for each PMU

\begin{tabular}{lcccc}
\hline \hline & Sioux PMU & Box Butte PMU & Garden PMU & Banner PMU \\
\hline Western Shortgrass Prairie (\%) & 69 & 48 & 20 & 43 \\
Agricultural land (\%) & 10 & 23 & 6 & 44 \\
Pine forest (\%) & 6 & - & - & - \\
Sandhill Upland Prairie (\%) & 5 & 19 & 64 & - \\
Mixed-grass Prairie (\%) & 4 & - & - & - \\
Tallgrass Prairie (\%) & - & 3 & 5 & \\
\hline
\end{tabular}

Note: This table was modified from the version reported in Hoffman et al. (2010)

pronghorn and could impede a pronghorn's ability to detect predators. The higher proportion of males in the Sioux PMU is most likely due to the higher quality of habitat (i.e., shortgrass prairie) found in this area. Mortality rates in pronghorn are typically male-biased and are often higher in lower quality habitat (Byers, 1997; O'Gara, 2004). This pattern has been documented on a captive population of pronghorn in Cheyenne County, NE, where range conditions were considered of lesser quality (Suetsugu, 1965). In this population winter mortality was consistently biased towards males.

In two of the four PMUs, the number of bucks harvested in the previous year's pronghorn hunting season significantly explained annual variation in pronghorn ASR. In the Sioux Unit, buck harvest was the only variable that could significantly explain annual variation in the ASR. In the Garden PMU, buck harvest and pronghorn density had an additive effect on the ASR. During years with lower densities and lower number of bucks harvested the ASR in the Garden Unit increased. Sex selective harvesting has an obvious direct effect on ASRs, especially in sexually dimorphic ungulates, by disproportionately increasing the mortality of males. The bias towards a male dominated harvest is justified by the polygynous mating system of most ungulates including pronghorn. Because only a few males are needed to mate with several females, removing excess males from a population is possible while still conserving the reproductive potential of the population. However, overharvesting can decrease the ASR to a point where there is a negative effect on female reproduction (Milner et al., 2007). This effect can be compounded, if there is an additional age bias in the harvest where hunters are removing large numbers of older males that typically do most of the breeding. The negative effects can be caused by changes in the timing and synchrony of breeding (White et al., 2001; Solberg et al., 2002), or females delaying or avoiding breeding because they are not able to find enough suitable mates (Ginsberg and Milner-Gulland, 1994; Komers et al., 1999; Møller and Legendre, 2001; Milner-Gulland et al., 2003).

The hunting strategies for pronghorn in Nebraska have varied considerably since the first hunting season was opened in 1953 (Hoffman et al., 2011) and could have affected our results. Initially, the hunting season for pronghorn lasted $3 \mathrm{~d}$ until 1970 when it was lengthened to a $9 \mathrm{~d}$ season. This extra time allowed hunters to be more selective, often resulting in a higher harvest of bucks. For instance, in the years 1969, 1970, and 1971 the percentage of adult bucks harvested increased in the Garden and Sioux PMUs from 63\%, $68 \%, 71 \%$ and $41 \%, 46 \%, 51 \%$, respectively. However, this annual increase in buck harvest was not observed in the Banner $(64 \%, 50 \%, 51 \%)$ or Box Butte $(59 \%, 53 \%, 63 \%)$ units. Coincidently, the number of bucks harvested was significant in predicting pronghorn ASRs in the Garden and Sioux PMUs but not in the Banner or Box Butte units. One explanation for this discrepancy could be difference in landowner/hunter attitudes across units. 
Attitudes toward pronghorn tend to decline as levels of crop depredation increase. The percentage of agricultural ground is much higher in the Banner and Box Butte PMUs compared to the Garden and Sioux units (Table 4). Thus, in the Banner and Box Butte units it's plausible that landowners and/or hunters were more concerned with reducing pronghorn numbers by harvesting bucks and does, than they were with selecting an adult buck. In Banner County, NE, special permits were issued because of high levels of crop depredation by pronghorn from 1961-1963. In those 3 y a total of 41 (23 ○", 18 o), 80 (42 O", 38 ᄋ), and 126 (80 ○*, 46 ○) pronghorn were harvested. Subsequently, this prompted the creation of the Banner PMU in 1964.

Pronghorn density in the previous year was correlated to pronghorn ASR in the Box Butte and Garden PMUs. In these two units, ASRs are more female-biased at higher densities and less female-biased at lower densities. The causal mechanism of the relationship between ASRs and density, however, is difficult to interpret. The difficulty comes primarily through the lack of data on birth sex ratios of pronghorn and subsequent fawn survival. These variables are most important to determining a populations ASR (Lee et al., 2011). Densitydependent birth sex ratios has been documented (Walker et al., 2010), but more data are need to ascertain whether this pattern is present in pronghorn.

Variation in the importance of predictor variables among the PMUs was an interesting result. No one variable or specific combination of variables significantly explained annual fluctuations in pronghorn ASR for all four populations. Most surprising was that the number of bucks harvested was significant for only two of the PMUs (Sioux and Garden). The number of males taken directly out of a population would naturally be expected to effect the populations ASR. The fact that buck harvest was not an important variable for the Box Butte and Banner PMUs and that all populations exhibited variation in their predictor variables has interesting management implications. Based on our results, these populations are being regulated independently, indicating that managers should develop management plans that are population specific. For example, it may not be prudent to use the same criteria for setting harvest limits in all PMUs, given the impact of buck harvest is variable across populations. We suggest this variability in importance of explanatory variables is due to difference in landcover and landuse characteristics among the PMUs. Inconsistencies in predictor variables for pronghorn density and Jul. fawn: doe ratios also were observed in these four PMUs (Hoffman et al., 2010).

We have shown a correlative relationship between the ASR of pronghorn and density in two PMUs (Box Butte and Garden) in western Nebraska. Also the number of pronghorn bucks harvested in the previous year significantly affected the ASR in the Sioux and Garden PMUs. Our results provide a foundation for understanding the role of ASRs in pronghorn population dynamics, as well as identifying several avenues for future research. Most notably this includes the need for information on variation in pronghorn birth sex ratios and fawn survival. Also, the possibility of pronghorn density, harvest, and ASRs serving as a casual mechanism for the Allee effect could be productive areas of inquiry. For instance, when the ASR is balanced there are an excess of males compared to normal years. This could lead to more time devoted to male-male aggression or to increased aggression towards females and reduce their survival and fecundity rates (Le Galliard et al., 2005). Data on male age structure and behavior towards female pronghorn across varying densities are needed to determine if there is an effect on female fitness and fecundity. Another factor that might facilitate an Allee effect in these populations includes a loss of antipredator strategies (Lande, 1998; Kramer et al., 2009). As density decreases fewer individuals are available to be vigilant for predators. Data on predation rates and predator vigilance, as it relates to varying 
densities of pronghorn, are needed to determine whether there is a decrease in antipredator defense at lower densities.

Acknowledgments.-Bruce Trindle and Jeff Hoffman of the Nebraska Game and Parks Commission provided access to these data. Rachel Jones assisted with the initial data collection. All information used for this study on pronghorn populations was taken from the Pittman-Robertson W-15-R Pronghorn Job Completion Report series compiled by the Nebraska Game and Parks Commission (NGPC). This information summarized all work conducted on an annual basis by the NGPC as it pertained to the management of pronghorn in Nebraska. This included inventory and monitoring of populations, harvest records, and various special projects. W. Sue Fairbanks provided comments on an earlier version of the manuscript.

\section{Literature Cited}

Allee, W. C. 1931. Animal aggregations: a study in general sociology. University of Chicago Press, Chicago, Illinois.

Bender, L. C. And P. J. Miller. 1999. Effects of elk harvest strategy on bull demographics and herd composition. Wildl. Soc. Bull., 27:1032-1037.

Berger, J. AND M. E. Gomprer. 1999. Sex ratios in extant ungulates: products of contemporary predation or past life histories? J. Mammal., 80:1084-1113.

Bessa-Gomes, C., S. Legendre, and J. Colbert. 2004. Allee effects, mating systems and the extinction risk in populations with two sexes. Ecol. Lett., 7:802-812.

ByERs, J. A. 1997. American pronghorn: social adaptions and the ghosts of predators past. University of Chicago Press, Chicago, Illinois. 300 p.

- AND J. D. Moodie. 1990. Sex-specific maternal investment in pronghorn, and the question of a limit on differential provisioning in ungulates. Behav. Ecol. Sociobiol., 26:157-164.

Burnham, K. P. and D. R. Anderson. 2002. Model selection and multimodel inference. 2nd ed. SpringerVerlag Inc., New York, New York. 488 p.

Castro, I., K. M. Mason, D. P. Armstrong, and D. M. Lambert. 2004. Effect of extra-pair paternity on effective population size in a reintroduced population of the endangered hihi, and potential for behavioural management. Conserv. Genet., 5:381-393.

Clutton-Brock, T. H., K. E. Rose, And F. E. Guinness. 1997. Density-related changes in sexual selection in red deer. Proc. R. Soc. B., 264:1509-1516.

—, T. N. Coulson, E. J. Milner-Gulland, D. Thomson, and H. M. Armstrong. 2002. Sex differences in emigration and mortality affect optimal management of deer populations. Nature, 415:633-637.

Courchamp, F., T. Clutton-Brock, and B. Grenfell. 1999. Inverse density dependence and the Allee effect. Trends Ecol. Evol., 14:405-410.

Deblinger, R. D., A. W. Alldredge, and L. Saslaw. 1984. Migratory patterns of pronghorn in the Red Desert, Wyoming. Proc. Pronghorn Antel. Works., 11:90-91.

Donald, P. F. 2007. Adult sex ratios in wild bird populations. Ibis, 149:671-692.

Engen, S., R. LANdE, ANd B. E. SÆTher. 2003. Demographic stochasticity and Allee effects in populations with two sexes. Ecology, 84:2378-2386.

Ginsberg, J. R. and E. J. Milner-Gulland. 1994. Sex-biased harvesting and population dynamics in ungulates: implications for conservation and sustainable use. Conserv. Biol., 8:157-166.

Hoffman, J. D., H. H. Genoways, and R. R. Jones. 2010. Factors influencing long-term population dynamics of pronghorn (Antilocapra americana): evidence of an Allee effect. J. Mammal., 91:1124-1134.

— — - AND — 2011. Historical biogeography of Nebraska pronghorns (Antilocapra americana). Great Plains Res., 21:153-173.

Komers, P. E., B. Birgersson, and K. Ekvall. 1999. Timing of estrus in fallow deer is adjusted to the age of available mates. Am. Nat., 153:431-436.

Kramer, A. M., B. Dennis, A. M. Liebhold, and J. M. Drake. 2009. The evidence for Allee effects. Popul. Ecol., 51:341-354. 
LANDE, R. 1998. Demographic stochasticity and Allee effect on a scale with isotropic noise. Oikos, 83:353-358.

Leathwick, J. R., D. Rowe, J. Richardson, J. Elith, and T. Hastie. 2005. Using multivariate adaptive regression splines to predict the distributions of New Zealand's freshwater diadromous fish. Freshw. Biol., 50:2034-2052.

LeE, A. M., B.-E. SÆTher, AND S. Engen. 2011. Demographic stochasticity, Allee effects, and extinction: the influence of mating system and sex ratio. Am. Nat., 177:301-313.

Le Galliard, J.-F., P. S. Fitze, R. Ferrière, and J. Clobert. 2005. Sex ratio bias, male aggression, and population collapse in lizards. Proc. Natl. Acad. Sci. U.S.A., 102:18231-18236.

MAHER, C. R. 1991. Activity budgets and mating system of male pronghorn antelope at Sheldon National Wildlife Refuge, Nevada. J. Mammal., 72:739-744.

McLoughuin, P. D., M. K. Taylor, and F. Messier. 2005. Conservation risks of male-selective harvest for mammals with low reproductive potential. J. Wildl. Manage., 69:1592-1600.

Milner, J. M., E. B. Nilsen, And H. P. Andreassen. 2007. Demographic side effects of selective hunting in ungulates and carnivores. Conserv. Biol., 21:36-47.

Milner-Gulland, E. J., O. M. Bukreeva, T. Coulson, A. A. Lushchekina, M. V. Kholodova, A. B. Bekenov, AND I. A. GRACHEv. 2003. Reproductive collapse in saiga antelope harems. Nature, 422:135.

Møller, A. P. ANd S. Legendre. 2001. Allee effect, sexual selection, and demographic stochasticity. Oikos, 92:27-34.

MurraY, B. G. 1991. Measuring annual reproductive success, with comments on the evolution of reproductive behavior. Auk, 108:942-952.

Ockenfels, R. A., C. L. Dorothy, And J. D. Kirkland. 1992. Mortality and home range of pronghorn fawns in central Arizona. Proc. Pronghorn Antel. Works., 15:78-92.

O'GARA, B. W. 2004. Mortality factors, p. 379-394. In: B. W. O'Gara and J. D. Yoakum (eds.). Pronghorn ecology and management. University Press of Colorado, Boulder, Colorado, USA.

AND J. D. Yoakum. 2004. Pronghorn: ecology and management. University Press of Colorado, Boulder, Colorado. 903 p.

Pojar, T. M., D. C. Bowden, ANd R. B. Gill. 1995. Aerial counting experiments to estimate pronghorn density and herd structure. J. Wildl. Manage., 59:117-128.

R Development Core Team. 2008. R: a language and environment for statistical computing. $R$ Foundation for Statistical Computing, Vienna, Austriahttp://www.R-project.org. Accessed 4 May 2011.

Sæther, B.-E., S. Engen, R. Lande, A. P. Møller, S. Bensch, D. Hasselquist, J. Beier, and B. Leisler. 2004. Time to extinction in relation to mating system and type of density regulation in populations with two sexes. J. Anim. Ecol., 73:925-934.

Solberg, E. J., A. Loison, T. H. Ringsby, B.-E. SÆther, And M. Heim. 2002. Biased adult sex ratio can affect fecundity in primiparous moose Alces alces. Wildl. Biol., 8:117-128.

V. Grotan, C. M. Rolandsen, H. Broseth, and S. Brainerd. 2005. Change-in-sex ratio as an estimator of population size for Norwegian moose Alces alces. Wildl. Biol., 11:163-172.

Stephens, P. A., W. J. Sutherland, And R. P. Freckleton. 1999. What is the Allee effect. Oikos, 87:185-190.

Suetsugu, H. 1965. Surveys and management of antelope, p. 52-62. In: Job Completion Report, Mar. 1, 1964 to Feb. 29, 1965, Pittman-Robertson Project W-15-R-21, Nebraska Game, Forestation and Parks Commission, Lincoln. 16 p.

Trivers, R. L. and D. E. Willard. 1973. Natural selection of parental ability to vary the sex ratio of offspring. Science, 179:90-92.

Walker, S. P. W., L. Thibaut, and M. I. McCormick. 2010. Density-dependent sex ratio adjustment and the Allee effect: a model and a test using a sex-changing fish. Am. Nat., 176:312-321.

WEDEKIND, C. 2002. Manipulating sex ratios for conservation: short-term risks and long-term benefits. Anim. Conserv., 5:13-20.

White, G. C., D. J. Freddy, R. B. Gill, and J. H. Ellenberger. 2001. Effect of adult sex ratio on mule deer and elk productivity in Colorado. J. Wildl. Manage., 65:543-551.

Wildt, D. E. and C. Wemmer. 1999. Sex and wildlife: the role of reproductive science in conservation. Biodivers. Conserv., 8:965-976. 
Woolley, T. P. And F. G. Lindzey. 1997. Relative precision and sources of bias in pronghorn sex and age composition surveys. J. Wildl. Manage., 61:57-63.

YOAKUM, J. D. 2004. Habitat characteristics and requirements, p. 409-445. In: B. W. O'Gara and J. D. Yoakum (eds.). Pronghorn ecology and management. University Press of Colorado, Boulder, Colorado, USA. 